\title{
New Treatment for Dentistry Regeneration Based on Metronidazole Release from Collagen/Strontium Sponges
}

\author{
MIRCEA RIVIS ${ }^{1 *}$, ALICE G. SIMONCA ${ }^{2 *}$, MARIA M. MARIN ${ }^{2,3}$, ADINA NORA VALEANU1*, ILEANA RAU2*, \\ MADALINA G. ALBU KAYA ${ }^{3}$, EMILIA IANES ${ }^{1}$, CIPRIAN CHELARU 3 , CRISTINA DINU PIRVU, ${ }^{4}$, MIHAELA V. GHICA ${ }^{4}$ \\ ${ }^{1}$ Victor Babes University of Medicine and Pharmacy from Timisoara, Faculty of Dentistry, 2 Eftimie Murgu Sq., 300041, Timisoara, \\ Romania \\ ¿University Politehnica of Bucharest, Faculty of Applied Chemistry and Materials Sciences, 1-7 Gh. Polizu Str., 011061, Bucharest, \\ Romania \\ ${ }^{3}$ Collagen Department, INCDTP - Leather and Footwear Research Institute, 93 Ion Minulescu Str., 031215, Bucharest, Romania \\ ${ }^{4}$ Carol Davila University of Medicine and Pharmacy, Faculty of Pharmacy, Physical and Colloidal Chemistry Department, \\ 6 TraianVuia Str., 020956, Bucharest, Romania
}

\begin{abstract}
It is well known that periodontitis causes rapid destruction of gingival and bone tissues. Topical treatments are suitable because the drug can be delivered in a proper and controlled concentration. Metronidazole proved to be efficient for patients with aggressive periodontitis. By this study we aimed to obtain spongious drug delivery systems for local periodontitis treatment based on collagen, strontium renalate and metronidazole. Collagen spongious forms were obtained by lyophilisation of composite gels based on collagen:strontium ranelate (50:50) and different concentrations of metronidazole. The obtained spongious forms were characterized by FT-IR, water up-take, optic microscopy and in vitro release of metronidazole. The prepared matrices absorbed a maximum amount of water after $30 \mathrm{~min}$. The most absorbent sample is the reference one (only collagen) which absorbed about 35\% water; the adding of metronidazole decrease the water absorption due to its lipophilic behavior. The samples with strontium are more compact and they absorbed less water than the ones without strontium. Because the samples were not cross-linked they degrade during $24 \mathrm{~h}$ of water absorption process. The drug percentage released was influenced by the drug and strontium ranelate concentrations. The analysis performed sponges indicate that these composites can be useful as drug delivery supports.
\end{abstract}

Keywords: collagen, metronidazole, strontium ranelate, drug release

Periodontitis represents the chronic gingival inflammation that affects the soft tissue and the bone that supports the teeth [12].This damage leads to the destruction of the alveolar bone surrounding the teeth. The most important tissue implicated in retaining teeth arch is the alveolar bone, which in periodontal conditions endures demineralization [2]. Teeth support is reduced as the supporting structures are deteriorated, this causing changes in resorption and in the occurrence of periodontal holes which produce severe exudates, favorable environment for the development and proliferation of bacteria [6]. Periodontal disease is considered a major health problem globally, and severe forms of this disease affect about $11 \%$ of the adult population [5]. Research over the lastfew years has shown that periodontal conditions have a negative impacton the quality of life related to oral health and patient life, including impairment, functional limitations, discomfort and disability [1]. This disease is influenced by several factors, the main factor in the progression of the illness is the bacterial plaque [19]. The bacteria adhere to the teeth surface and a biofilm is slowly formed. When oral hygiene is not performed properly, gingivitis occurs and progresses to periodontitis $[7,9]$. Other factors that cause periodontal disease are: genetics, smoking, pregnancy, stress, alcohol, socio-economic status, gender and ethnicity [15]. Different treatments, especially the oral administration of antimicrobial agents are used at present to patients. However, topical treatments are more suitable because the drug can be delivered to the affected site in a proper and controlled concentration [3]. Such treatment can be also model for targeted drug delivery systems and local administrated to different types of cancer such as prostate, lung, liver ones [21-23]. Metronidazole is a bactericidal antimicrobial agent indicated for use against a restricted number of anaerobic organisms proved to be efficient for management of patients with aggressive periodontitis [10]. Metronidazole is bactericidal to anaerobic germs and has the role to suspend bacterial DNA synthesis in terms with a low reduction potential [16]. Collagen is a material that can be widely used in medical, dental and pharmacological fields because it is used in various forms, membranes, porous matrices, gels etc. [13]. In recent years, collagen as a carrier for drug delivery is very used by many researchers throughout the w orld [14]. Bioresorbable forms of collagen have been used for healing oral damages, for closure extraction sites [17]. Collagenbased membranes have also been used in periodontal and implant therapy as barriers to impede epithelial migration and allow cells with regenerative capacity to repopulate the defect area creating a favourable environment for periodontal and peri-implant regeneration [8]. Another agent that is clinically used to prevent bone loss in periodontitis patients is strontium ranelate [20]. Recently studies have showed that it simultaneously acts by both growing bone formation and retarding bone resorption thus demonstrating increases in bone mineral density in clinical trials [4].

By this study we aimed to obtain spongious drug delivery systems for local periodontitis treatment based on collagen, strontium ranelateand metronidazole.

\section{Experimental part}

Collagen spongious forms were obtained by lyophilisation of composite gels based on collagen: 
strontium ranelate in ratio of 50:50 (Coll:SrR) and different concentrations of metronidazole (MTZ). All the composite gels were adjusted at $p \mathrm{H}=7.4$ - physiological $p \mathrm{H}$. The obtained spongious forms (matrices) were characterized byFT-IR, using spectrophotometer J asco FT/IR-4200, optic microscopy using Leica Stereomicroscope model S8AP0, with a 20-160x magnification capacity and water up-take.In order to determine the water absorption, the collagen matrices were first immersed in water. At scheduled time intervals, the samples were withdrawn and weighed. The water absorption was calculated using the following equation:

$$
\% \text { Water up-take }=(\mathrm{Wt}-\mathrm{Wd}) / \mathrm{Wd}(\mathrm{g} / \mathrm{g})
$$

where $\mathrm{Wd}$ denotes the weight of the dry samples and $\mathrm{Wt}$ denotes the weight of the swollen samples at immersion time $t$.

The in vitro metronidazole release from the designed sponges was carried out with a sandwich device adapted to paddle dissolution equipment (Esadissolver), as we previously reported [11, 18]. To establish the drug release mechanism, different kinetic models were applied to the experimental data - the Power law model (eq. 2) and its particular cases: Higuchi (eq. 3) and Zero order (eq. 4)

$$
\begin{aligned}
\frac{\mathrm{m}_{\mathrm{t}}}{\mathrm{m}_{\infty}} & =\mathrm{k} \cdot \mathrm{t}^{\mathrm{n}} \\
\frac{\mathrm{m}_{\mathrm{t}}}{\mathrm{m}_{\infty}} & =\mathrm{k} \cdot \mathrm{t}^{0.5} \\
\frac{\mathrm{m}_{\mathrm{t}}}{\mathrm{m}_{\infty}} & =\mathrm{k} \cdot \mathrm{t}
\end{aligned}
$$

where $m / m_{\alpha}$ is the fractional release of drug at time $t, k$ the kinetic constant, $\mathrm{n}$ - the release exponent showing the drug release mechanism.

\section{Materials}

Type I collagen gel (COL) was extracted from calf hide using technology developed at the Research-Development Textile Leather National Institute Division Leather and Footwear Research Institute - Collagen Department [13].Metronidazolewas purchase from Hubei Hongyuan Pharmaceutical technology CO., Ltd., China and SrRfrom OSSEOR.

The collagen gel with the initial acid $\mathrm{pH}$ and $1.1 \%$ concentration was adjusted using $1 \mathrm{M}$ sodium hydroxide at physiological $\mathrm{pH}$ - 7.3 for a better biocompatibility. The final concentration of used collagen gel was $1 \%(\mathrm{w} / \mathrm{v})$. Thereafter strontium renelate was added in ration of 50:50 COLL:SrR, and different concentrations of metronidazole (MTZ) according to the compositions shown in table 1.

All the composite samples obtained were freeze-dried using Delta 2-24 LSC (Martin Christ, Germany) lyophilizer, using a $48 \mathrm{~h}$ lyophilisation program, in order to obtain spongious forms for future characterization.

\section{Results and discussions}

All the samples obtained after lyophilisation were analyzed firstly using FT-IR spectroscopy in order to demonstrate the presence of collagen, strontium and metronidazole considering that this analysis in qualitative not qualitative. Results recorded after spectroscopy analysis, are presented in figure 4.

From figure 4 can be noticed that the spectrum of collagen matrix exhibited typical amide bands of proteins i.e. $3279 \mathrm{~cm}^{-1}$ and $2955 \mathrm{~cm}^{-1}$ for amide $A$ and $B$ respectively, $1632 \mathrm{~cm}^{-1}$ was ascribed to amide I ( $C=0$ stretching), 1547 $\mathrm{cm}^{-1}$ to amide II (N-H deformation) and $1239 \mathrm{~cm}^{-1}$ to amide III (N-H deformation).

The MT spectrum shows their characteristics bands: $3200-3600 \mathrm{~cm}^{-1}$ attributed to the $0-\mathrm{H}$ stretching, 3221-3101 $\mathrm{cm}^{-1}$ (N-H stretching), $2982-2937 \mathrm{~cm}^{-1}$ (C-H stretching),

\begin{tabular}{|l|c|c|c|}
\hline & Collagen, $\%$ & Metronidazole,$\%$ & $\begin{array}{c}\text { Strontium } \\
\text { renalate**,\% }\end{array}$ \\
\hline COLL & 1 & 0 & 0 \\
\hline COLL-M1 & 1 & 0.75 & 0 \\
\hline COLL-M2 & 1 & 1.5 & 0 \\
\hline COLL-M3 & 1 & 2.25 & 0 \\
\hline COLL-Sr & 1 & 0 & 1 \\
\hline COLL-Sr-M1 & 1 & 0.75 & 1 \\
\hline COLL-Sr-M2 & 1 & 1.5 & 1 \\
\hline COLL-Sr-M3 & 1 & 2.25 & 1 \\
\hline
\end{tabular}

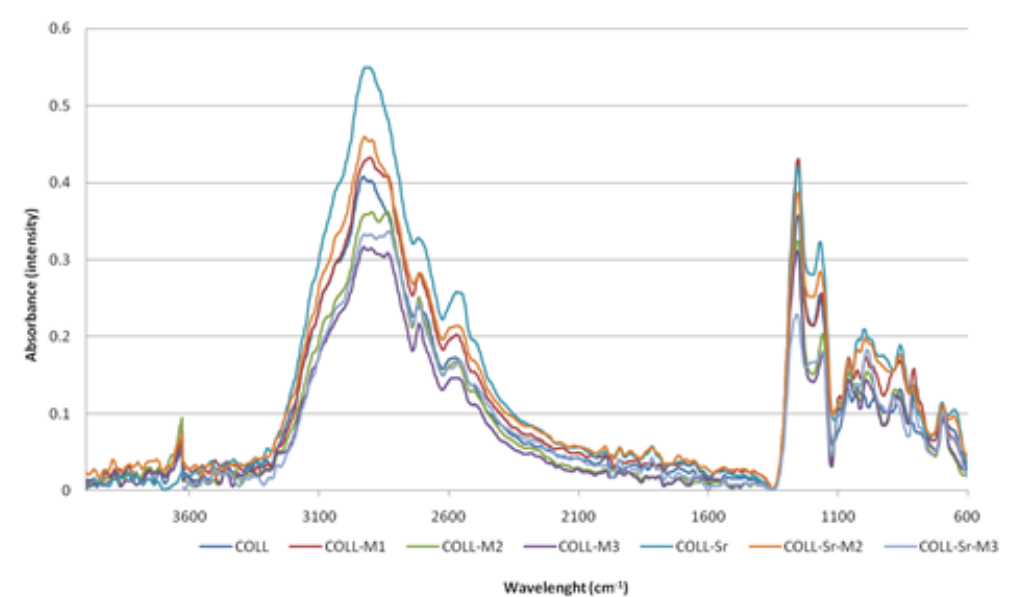

Fig.1. FT-IR spectra of obtained matrices 


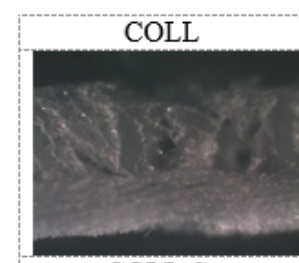

COLL-Sr
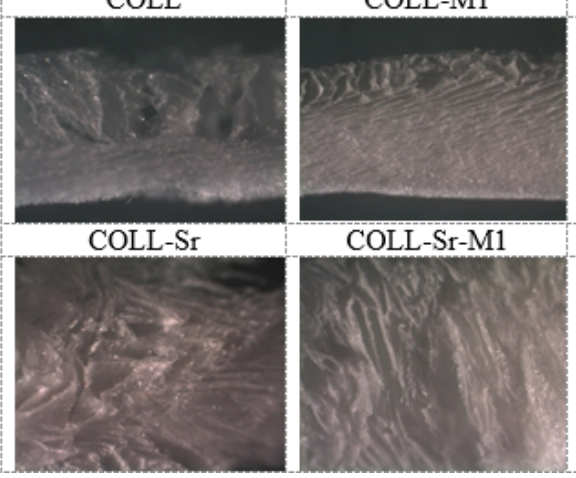

COLL-Sr-M1
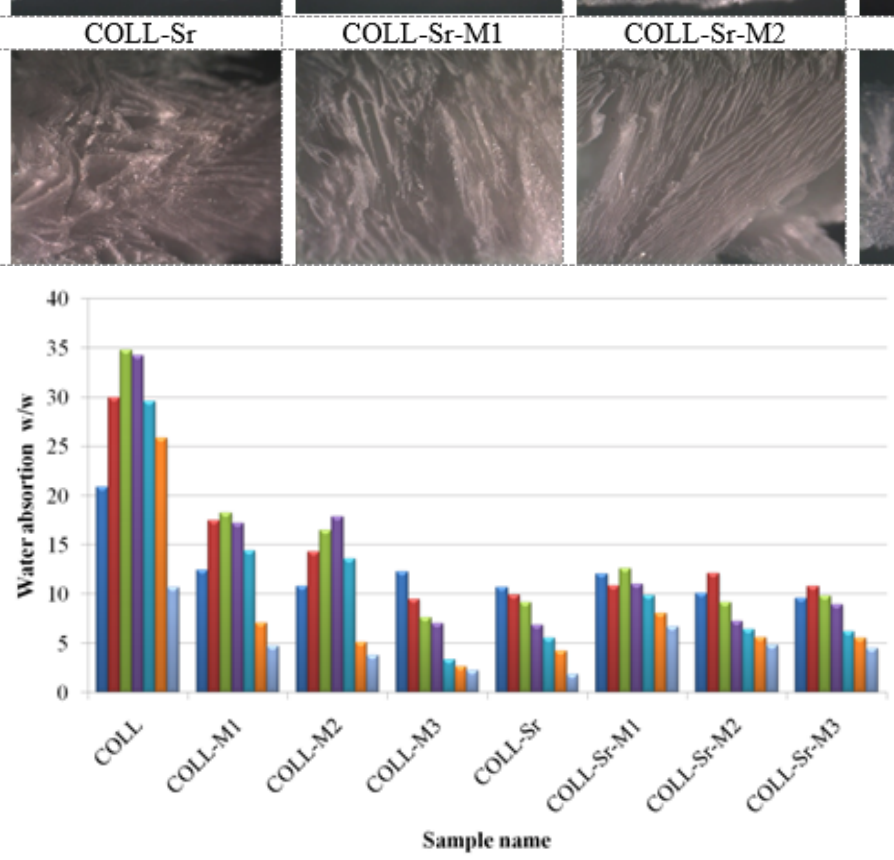

$1300-1600 \mathrm{~cm}^{-1}$ attributed to the $\mathrm{NO}_{2} ; 1354-1180 \mathrm{~cm}^{-1}$ (C0 stretching), $1428-1368 \mathrm{~cm}^{-1}$ (C-H bending, in plane), and $1340 \mathrm{~cm}^{-1}$ (C-C stretching) (Noheman et al, 2017).

The images obtained from optic microscopy are showed in figure 2.

Figure 2 illustrates the specific morphology of fibrilar collagen, with interconnected pores and also it can be observed that the collagen structure is not modified when the metronidazole was added. It can be noticed a that the collagen structure is more compact for the samples with strontium renalat. The porous structure of collagen matrices induced the ability to absorb water and also and in the same time to eliminate the drugs in order to act on periodontal disease. Also, obtained collagen sponge can be used for dental bone regeneration because during water absorbtion, besides drug release, the degradation occurs, as can be seen in figure 3 .

Figure 3 shows that the prepared matrices absorbed a maximum amount of water after 20 min. The most absorbent sample is the reference one (only collagen)

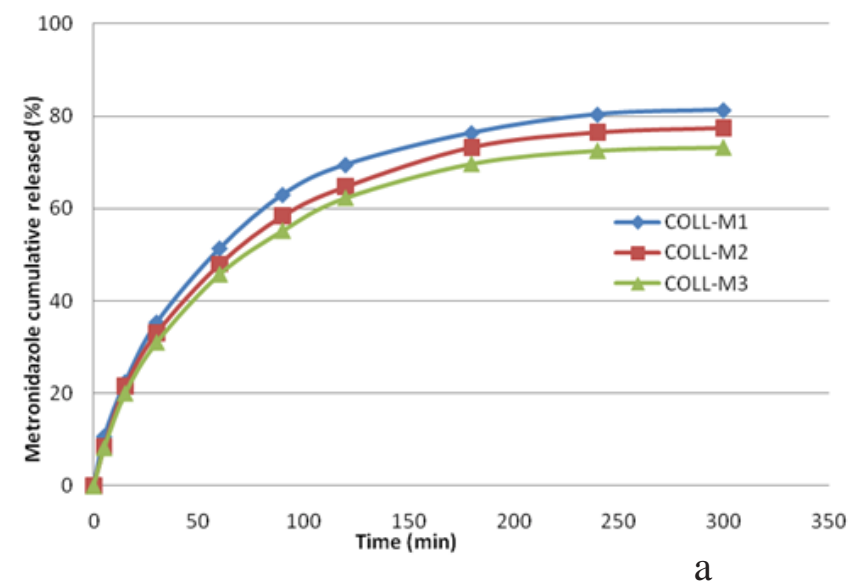

Fig.2. Optical microscopy images, $32 \mathrm{X}$ magnification.

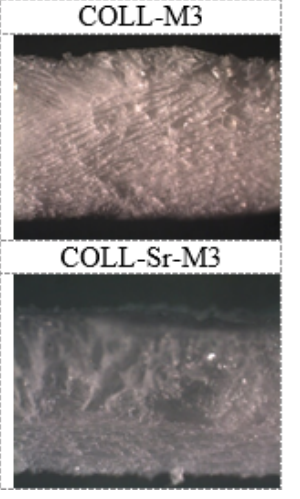

$\pm 20 \mathrm{~min}$

घ $30 \mathrm{~min}$

a $40 \mathrm{~min}$

घ $50 \mathrm{~min}$ $\square 2+\mathrm{h}$
Fig. 3. Water up-take capacity, measured for $24 \mathrm{~h}$

which absorbed about $35 \mathrm{w} / \mathrm{w}$ water. The adding of metronidazole decreases the water absorption capacity due to its lipophilic behavior. The samples with strontium are more compact as optical images showed and they absorbed less water than the ones without strontium. Because the samples were notcross-linked they have been degrade after $24 \mathrm{~h}$ of water absorption process.

The cumulative percentages of in vitro metronidazole released from the collagen sponges recorded as a function of time are presented in figure $4 a-b$.

From figure $4 a-b$ it can be remarked that in the first 30 $60 \mathrm{~min}$, the drug is rapid release, ensuring a diminution of bacteria at the periodontal pocket, followed by the a gradual release over about $4 \mathrm{~h}$ of experiments, ensuring a protective local antibacterian effect over a longer period of time. The cumulative metronidazolepercentage released varied between 73.18 (CoLL-M3) and 95.09\% (COLL-Sr-M2). It can be noticed that the addition of strontium ranelate in formulation induced an increase of drug percentage released for all sponges about 1.12-1.23 times.

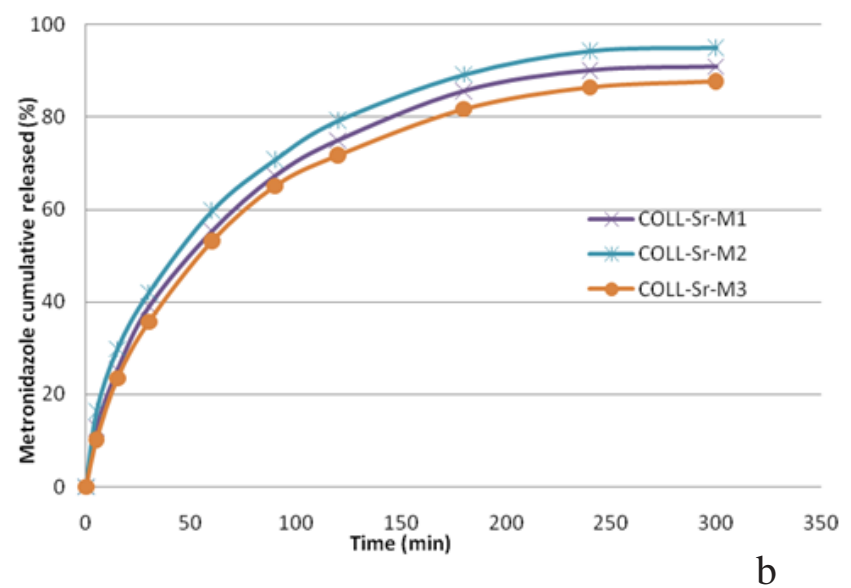

Fig. 4. Cumulative release profiles of metronidazole from collagen matrices: a) without $S r ; b$ ) with $S r$, as a function of time 


\begin{tabular}{|c|c|c|c|c|c|c|c|}
\hline Collagen sponges & Zero-order & Higuchi & Power law & $\begin{array}{l}\text { Kinetic } \\
\text { constant } \\
\left(1 / \mathrm{min}^{\mathrm{n}}\right)\end{array}$ & $\begin{array}{l}\text { Release } \\
\text { exponent }\end{array}$ & $\begin{array}{c}\text { Drug } \\
\text { percentage } \\
\text { released (\%) }\end{array}$ & $\begin{array}{c}\text { Table2 } \\
\text { CORRELATION } \\
\text { :OEFFICIENTS FOR MTZ } \\
\text { RELEASE FROM }\end{array}$ \\
\hline COLL-M1 & 0.8780 & 0.9720 & 0.9830 & 0.099 & 0.38 & 81.32 & COLLAGEN SPONGES \\
\hline COLL-M2 & 0.8845 & 0.9749 & 0.9840 & 0.088 & 0.39 & 77.39 & APPLICATION OF ZERO- \\
\hline COLL-M3 & 0.8825 & 0.9737 & 0.9829 & 0.084 & 0.39 & 73.17 & ORDER, HIGUCHI AND \\
\hline COLL-Sr-M1 & 0.8919 & 0.9790 & 0.9879 & 0.105 & 0.39 & 90.92 & $\begin{array}{l}\text { POWER LAW MODELS; } \\
\text { KINFTIC PARAMFTFR }\end{array}$ \\
\hline COLL-Sr-M2 & 0.8867 & 0.9777 & 0.9901 & 0.124 & 0.37 & 95.09 & FOR POWER LAW \\
\hline COLL-Sr-M3 & 0.8933 & 0.9789 & 0.9863 & 0.095 & 0.40 & 87.78 & \\
\hline
\end{tabular}

To set the drug release mechanism from the tested formulations various kinetic models were used: Power law, Higuchi and Zero-order models (eqs. 2-4).The corresponding correlation coefficients for the above models are listed in table 2.

As can be seen from table 2, the highest values for the determination coefficients were recorded for the Power law model, indicating formetronidazole release from the designed formulations a non-Fickian drug delivery mechanism (the values obtained for the release exponent are smaller than 0.5). The fiting parameters for the Power law model are listed in table 2.

\section{Conclusions}

The biopharmaceutical and physico-chemical analysis of the designed sponges indicate that these composites can be useful as drug delivery supports with potential use in the treatment of bone dental regeneration as well as for periodontal disease.

\section{References}

1.ARIGBEDE AO, BABATOPE BO, BAMIDELE MK (2012) Periodontitis and systemic diseases: A literature review. J Indian SocPeriodontol. doi: 10.4103/0972-124X.106878

2.CIURBA A, LAZAR L, ANTONOAEA, P, GEORGESCU AM, VARI CE, TODORAN N (2015) In vitro/in vivo performance study of new metronidazole periodontal gel formulations. Farmacia

3.GRIFFITHS GS, AYOB R, GUERRERO A, NIBALI L, SUVAN J, MOLES DR, TONETTI MS (2011) Amoxicillin and metronidazole as an adjunctive treatment in generalized aggressive periodontitis at initial therapy or re-treatment: a randomized controlled clinical trial. J ClinPeriodontol. doi: 10.1111/j.1600-051X.2010.01632.x

4. HAO J , ACHARYA A, CHEN K, CHOU J, KASUGAI S, LANG NP (2013) Novel bioresorbable strontium hydroxyapatite membrane for guided bone regeneration. Clin Oral Implants Res. doi: 10.1111/clr.12289

5.HOLDE GE, OSCARSON N, TROVIK TA, TILLBERG A, JÖNSSON B (2017) Periodontitis prevalence and severity in adults: a cross-sectional study in norwegian circumpolar communities. J Periodontol. doi: 10.1902/jop.2017.170164

6.IROKAWA D, TAKEUCHI T, NODA K, GOTO H, EGAWA M, TOMITA S, SUGITO, H. NIKAIDO M, SAITO A (2017) Clinical outcome of periodontal regenerative therapy using collagen membraneand deproteinized bovine bone mineral: a 2.5 year follow up study. BMC Res Notes. doi:10.1186/s13104-017-2426-y

7.IWASAKI M, TAYLOR GW, AWANO S, YOSHIDA A, KATAOKA S, ANSAI T, NAKAMURA H (2017) Periodontal disease and pneumonia mortality in hemodialysis patients: A 7-year cohort. J ClinPeriodontol. doi: 10.1111/jcpe.12828

8.KHAN R, KHAN MH (2013) Use of collagen as a biomaterial: An update. J Indian SocPeriodontol. doi: 10.4103/0972-124X.118333

9.KIM J, AMAR S (2006) Periodontal disease and systemic conditions: a bidirectional relationship.Odontology.doi: 10.1007/s10266-006-0060-

10.LOESCHE WJ, SCHMIDT E, SMITH BA, MORRISON EC, CAFFESSE R, HUJ OEL PP (1991) Effects of metronidazole on periodontal treatment needs. J Periodontol. Doi: 10.1902/jop.1991.62.4.247

11.MARIN M, GHICA MV, SIMONCA AG, RAU I, ALBU KAYA MG, FERDES M, DINU-PIRVU C, CHIRITA C, POPA L (2016) Development and evaluation of some metronidazole-loaded collagen supports designed for periodontitis. In Proceedings of the 6th International Conference on Advanced Materials and Systems, Bucharest, Romania, 20-22 October 2016. pp. 275-280

12.MUMMOLO S, D'ERCOLE S, MARCHETTI E, CAMPANELLA V, MARTINELLI D, MARZO G, TRIPODI D (2014) Oral antiseptic and periodontitis: a clinical and microbiological study. Oral Health Dent Manag.

13.MURATA M, HUANG BZ, SHIBATA T, IMAI S, NAGAI N, ARISUE M (1999) Bone augmentation by recombinanthuman BMP-2 and collagen on adult rat parietal bone. Int J Oral Maxillofac Surg. doi: 10.1034/ j.1399-0020.1999.283280316.x

14.PATINO MG, NEIDERS ME, ANDREANA S, NOBLE B, COHEN RE (2002) Collagen as an implantable material in medicine and dentistry. J Oral Implantol. doi:10.1563/1548-1336(2002)028< 0220:CAAIMI> 2.3.C0;2

15.PERSSON GR, OHLSSON 0, PETTERSSON T, RENVERT S (2003) Chronic periodontitis, a significant relationship with acute myocardial infarction. Eur Heart J . doi:10.1016/j.ehj.2003.10.007

16.RAJ AGOPALAN A, THOMASJT (2014) effectiveness of metronidazole as local drug delivery in periodontal diseases - A review. IOSR-JDMS. doi: 10.9790/0853-13842528

17.RAO KP (1995) Recent developments of collagen-based materials for medical applications and drug delivery systems. J BiomaterSciPolym Ed. doi.org/10.1163/156856295X00526

18.TIHAN GT, RAU I, ZGARIAN RG, GHICA MV (2016) Collagen-based biomaterials for ibuprofen delivery. C R Chim.dx.doi.org/10.1016/ j.crci.2015.09.008

19.VERGANI SA, SILVA EB, VINHOLIS AH, MERCANTONIO RAC (2004) Systemic use of metronidazole in the treatment of chronic periodontitis: a pilot study using clinical, microbiological, and enzymatic evaluation. Braz Oral Res. doi: /S1517-74912004000200006 20.ZHANG Y, WEI L, WU C, MIRON RJ (2014) Periodontal regeneration using strontium-loaded mesoporous bioactive glass scaffolds in osteoporotic rats. PLoS One. doi:10.1371/journal.pone.0104527

21.BOCAN, E.V., MEDERLE, O, SARB, S., MINCIU, R., AGAPIE, D., RAICA, M., Romanian J ournal of Morphology and Embryology, 52, nr. 4, 2011, p. 1215-1218.

22.DJ ESKA, I.S., CEAUSU, R.A., GAJE, P.N., CIMPEAN, A.M., MEDERLE, O., NICODIN, A., TUDORACHE, V., RAICA, M., Archives of Biological Sciences, 65, nr. 4, 2013, p. 1599-1604.

23.RALUCA, B.A.,CIMPEAN, A.M., CIOCA, A., CRETU, O., MEDERLE, O., CIOLOFAN, A., GAJE, P., RAICA, M., Asian Pacific J ournal of Cancer Prevention, 16, nr. 11, 2015, p. 4549-4553.

Manuscript received: 14.11 .2017 